\title{
Transatlantica
}

Revue d'études américaines. American Studies Journal

Line Breaks in America: the Odds and Ends of Poetry

\section{Line Breaks in America: the Odds and Ends of Poetry}

\section{Chloé Thomas}

\section{(2) OpenEdition}

1 Journals

\section{Electronic version}

URL: https://journals.openedition.org/transatlantica/16870

DOI: $10.4000 /$ transatlantica. 16870

ISSN: 1765-2766

\section{Publisher}

Association française d'Etudes Américaines (AFEA)

\section{Electronic reference}

Chloé Thomas, "Line Breaks in America: the Odds and Ends of Poetry", Transatlantica [Online], 1| 2021, Online since 01 July 2021, connection on 31 January 2023. URL: http://journals.openedition.org/ transatlantica/16870 ; DOI: https://doi.org/10.4000/transatlantica.16870

This text was automatically generated on 31 January 2023

\section{(c) (i) (9)}

Creative Commons - Attribution-NonCommercial-NoDerivatives 4.0 International - CC BY-NC-ND 4.0 https://creativecommons.org/licenses/by-nc-nd/4.0/ 


\title{
Line Breaks in America: the Odds and Ends of Poetry
}

\author{
Chloé Thomas
}

I tended to find lines of poetry beautiful only when I encountered them quoted in prose, in the

essays my professors had assigned in college, where the line breaks were replaced with slashes,

so that what was communicated was less a

particular poem than the echo of poetic possibility. (Lerner, 2011 chap.1)

Ben Lerner's narrator, a young poet getting bored in Madrid while on a Fulbright, voices a feeling that may not be unfamiliar to readers of verse, as the success of Lerner's follow-up essay The Hatred of Poetry testifies. In the latter, commenting on this passage from Atocha (and presenting it as "an exaggerated version of [his] own experience"), Lerner evokes poets who voluntarily use the slash (Olson, Rankine) as a weaker manifestation of poetry exposing at the same time the insufficiency (and, in a way, the excess) of versification:

In the excerpts of Citizen that appeared in magazines and in the prepublication galleys circulated to reviewers, Rankine's poems were often preceded by, followed by, or broken up by slashes. The "/"-the technical term is "virgule"-is the conventional way of indicating a line break when verse is quoted in prose. I think it's notable that the virgule often appeared after or between prose passages in Citizen when it could be read as a typographical representation of verse's felt unavailability-or, to put it another way, verse's ghostly presence. (Lerner, 2016)

The "ghostly presence" indicated by the virgule, just like the resistance of Lerner's autofictive self to lines, is also a marker of the problem posed by line breaks: they are attention-seeking, signifying that a text demands to be regarded as poetry. It is certainly no accident that some well-versed postmodern poets prefer to avoid them, even staging their avoidance so as both to assert the genre they write in and to bypass the general distrust about what is still seen as its clearest formal feature. It is a feature that is neither necessary nor sufficient and yet so historically laden that it remains a core problem of contemporary poetics. In Atocha, Lerner writes of lines as "the echo of 
poetic"-not "versified" or "metric"-"possibility"; to his narrator, lines still mean poetry. While prose has proved flexible enough to accommodate a diversity of genres, lines have remained associated with only one, at least up through Lerner's generation (younger people, however, are in contact with the trendy versified young adult novel which is sometimes regarded, in a rather surprising twist, as easier to read than justified blocks of text (see for instance Beauvais)). Consequently, breaking lines is still seen both as a statement and a risk. As Lerner notes at the beginning of The Hatred of Poetry, most poetics are defensive, from Spenser's Defense of Poesy to Moore's "I, too, dislike it." Another poet and critic writes in the same tone:

[...] is this a line break

or am I simply chopping up ineradicable prose. But to defend this

(poem) from its own attack, I'll say that both the flush left

and irregular right margins constantly loom as significant events, often

interrupting what

I thought I was about to write and making me write something

else entirely. Even though I'm going back and rewriting, the problem still

reappears every six words. (Perelman 58)

2 In what seems at first sight an exercise in cut prose meant to expose the artificiality of line breaks, Bob Perelman comes to defend their seeming vacuity by constructing them as a tool of defamiliarization. In so doing, he very consciously plays with the suspicion that they are only "chopping up ineradicable prose," a suspicion which, this very poem confirms, has become widespread. Robert Pinsky noted in 1976, in The Situation of Poetry:

In general, the more any style is taken for granted, the more abusive the practice of it can become. Somewhere, on some campus in America, a young poet is writing a sentence with all or nearly all of the totemic words, something like:

The silence of my

Blood eats light like the

Breath of future water

which I have composed in less time than it takes to type, and which is the contemporary version of, say:

The fiery blossoms fading in the twilight. (Pinsky 165; quoted in Frank and Sayre $\mathrm{xv}-\mathrm{xvi}$ )

3 Pinsky's counterpoint to his fictional collegiate verse, "The fiery blossoms fading in the twilight," is of course a (made-up) iambic pentameter, whose theme is only adapted (more first person, same light) by the freshman writer. But, as Robert Frank and Henry M. Sayre point out in the introduction to their volume The Line in Postmodern Poetry, in which they quote this passage from Pinsky:

It is not merely the diction which is being abused in this example. It is also free verse, for the hard enjambments serve one purpose and one purpose only: they are markers which announce the hypothetical poet's very contemporaneity, this fictitious student's independence from traditional prosody. They are also, quite clearly, by now, a convention-albeit a convention announcing unconventionality. (Frank and Sayre xv-xvi)

4 The "fictitious student's independence" can be read as the fictitious independence of an absolutely realistic student from prosody and their dependence on free verse as a code and convention; it's pressing "Enter" at random to gain the right to say "I am a poet." Even though line breaks have ceased to obey precise metric rules and have lost their formal necessity, they are still, paradoxically, at the core of the question "what is poetry?", and even more so than before verse was "free." In an important paper 
entitled "The Linear Fallacy," meant to expose fake poems such as the one forged by Pinsky, Marjorie Perloff quotes a few lines from Karen Snow's Wonders (1978) to illustrate her point. Snow dismisses most of the "totemic words" (and images and sounds) and fails at writing poetry because, to Perloff, her text has nothing poetic about it except the lines:

Lineation here seems to be no more than a convenient way of packaging the material. Line breaks come after roughly thirty-five or forty ems so as to create a fairly symmetrical visual format; the spaces within the lines, moreover, seem designed to guarantee that we process this text as poetry rather than as prose. (Perloff, 1981 861-862)

5 Why, at a time when prose poems exist and are acknowledged, would a young poet resort to lines to "guarantee that we process this text as poetry"? Perloff quotes Jonathan Culler and his Structuralist Poetics performing for the sake of demonstration exactly what she accuses Snow of doing-cutting prose, namely a news item, to comment on the effect produced (in this case, turning a car accident into "a minor but exemplary tragedy"). Culler insists that this effect is dependent on the fact that, in our day and age, a versified text is an exception, an écart, from the norm of the prose text. As Perloff comments in another paper:

We must realize that the choice of verse form is not just a matter of individual preference, a personal decision to render a particular experience as a sonnet rather than a ballad, a prose poem rather than a free verse lyric, and so on. For the pool of verse and prose alternatives available to the poet at any given time has already been determined, at least in part, by historical and ideological considerations. (Perloff, 1988 39)

6 In the historically situated moment in which Perloff is writing "The Linear Fallacy," the current convention is that of free verse, as Frank and Sayre rightly noted, and its emergence seems to have been the major turning point from which line breaks came to be regarded as suspicious. T.E. Hulme, who died too soon to witness the full consequences of what he and a few others had started, saw the transcending of regular meter as a way to get closer to the essence of poetry beyond its form and, in doing so, to reveal that some broken lines are actually nothing but prose in disguise.

The criticism is sure to be made that when you have abolished the regular syllabled line as the unit of poetry, you have turned it into prose. of course this is perfectly true of a great quantity of modern verse. In fact, one of the great blessings of the abolition of regular metre would be that it would at once expose all this sham poetry. (Hulme 268)

Sham poetry: it is precisely what Perloff calls the "linear fallacy." But long before she came out with the phrase, many, poets and critics alike, had expressed a similar disdain, as if free verse, when mishandled, had indeed opened the possibility of producing the optical illusion of poetry. Who is afraid of "sham prose poems"? The block of prose as such means nothing and brings forth no expectations; it contains no illusory shimmer and can hardly be accused of seducing-leading astray-the reader.

"(To break the pentameter, that was the first heave)" (Pound, 1989 532): Ezra Pound in his Pisan gaol, with no other material than three books and his memories, was recalling the early moments of his modernism. Of Canto LXXXI this line has stuck out, for despite the parentheses that make it look like an offhand remark, it does encapsulate something of a testament, the breakthrough that has supposedly been bequeathed to subsequent generations of poets. And this, of course, even in the Pisan Cantos, is still about storytelling. The group Pound tried to organize in order to bring forth a 
"revolution of the word" emerged at a time when the iambic pentameter had already been, up to a point, outdated. After all, American poetry had had its great experimenters in the nineteenth century-Whitman, Poe, Dickinson. Yet they did not stage nor embrace a demolition venture as Pound would do. In fact, they did not so much as "break" the pentameter. Whitman's lines, typically, are in excess. Dickinson's cleave from the inside, exhibiting the form rather than destroying it. Pound broke.

He was an editor as much as a poet; editing, he cut. One afternoon in 1912, proofreading H.D.'s "Hermes of the Ways" in the tea room of the British Museum, he cut. As T.S. Eliot's very own obstetrician, bringing The Waste Land to light, he cut. Lines got shorter, or brisker (longer, but with a more abrupt enjambment). All for a short and brisk moment. "Our modernity," Pound announced in "Und Drang" (1911),

Nerve-wracked and broken, turns

Against time's way and all the way of things (Pound, 1976 169)

Turning: that's the line itself, the verse, verso; "against time's way," going counter to the previous rules of prosody (or what Pound reconstructed as such). Severing the verb from its complement, this couplet shows off the discrepancy between the line and the sentence. The turning of the verse is, in Pound's story, turning one's back to a certain tradition (that of the Victorian or genteel poetry); it is a breakthrough in form that goes, out of necessity, against the grain of its time. This radical turning point is described as a necessity. Yet, at the same time, "nerve-wracked and broken," all this modernity has something ominously sick to it ("Crying with weak and egoistic cries!", reads the next line). Very early in fact the modernists had grown conscious of the threat of excess and anarchy contained in the liberty they were taking with meter, and the line break came to be seen as the location of this risk. As James Scully put it much later: "the free verse line break is the unformulated space we have to maneuver in, to risk production in. The line break could be compared to what Althusser, in another context, called 'a wild practice"' (Scully 110). Were the modernists really born to be that wild? In "The Linear Fallacy," Marjorie Perloff uses as an epigraph a few words by Pound, from the relatively early "Retrospect" (1918), that seem to provide an addendum to the parenthesis in the much later Canto LXXXI: "Don't imagine that a thing will 'go' in verse just because iŤs too dull to go in prose" (Pound, 1918 99). There was the first heave, breaking the pentameter; soon afterwards came the second, sorting out between good and bad breaks, between real and fake poetry. For with phrases such as "sham poetry" or "linear fallacy," the question is not so much "what is poetry?" but "what is good poetry?"; what is the genuine poetry that finds its definition beyond mere form and through other, much more elusive qualities?

Denise Levertov's essay "On the Function of the Line," mostly a treatise on line breaks, provides examples of what she regards as bad poetry. There, she shows that the line break is a measuring instrument. Not only does it determine the length of a line but it has also become a unit of measurement to evaluate the quality of poetry. Levertov, poet and critic, writes here not so much for critics (contrary perhaps to Perloff, who exposes bad poets) to help them measure (estimate) the value of the poetry they read, but for poets to help them measure (tailor) the poetry they produce. She writes: "there is at our disposal no tool of the poetic craft more important, none that yields more subtle and precise effects, than the line-break if it is properly understood" (Levertov 30). Indeed, Levertov's paper is first and foremost a pedagogical statement, a lesson in negotiating the turn. The art of the break, Levertov reminds us, has to do with the 
understanding of its effects, and these rely on the dynamic relation between two elements, the syntax and the line. This in fact can be applied to any versified poetry, regardless of its meter or lack of meter: free verse, giving more room to manoeuvre the break, may have been a privileged form for testing the effects of the break, but these can also be played with within a regular prosodic pattern, where the sentence may be made to overflow. On the contrary, a kind of free-verse poetry which would take syntax itself as its unit of measurement (language poetry and the "new sentence," for a striking example) would not be that much troubled by the question of line breaks, or by the distinction between verse and prose for that matter. But when the line break consciously creates a tension between syntax and line (whether through excess or defect), then it becomes charged with meaning or, at the least, with effect. Williams's famous variations in "To A Poor Old Woman" can be read as an exercise in linebreaking, a testing of what it produces:

They taste good to her

They taste good

to her. They taste

good to her (Williams 383)

Reading these lines anew, James Longenbach comments:

Williams offers a programmatic version of effects he achieves more subtly in the poems of Spring and All: line endings work against the forward motion of the repeated syntax, isolating particular words and forcing us to create a different pattern of emphasis with each repetition. (Longenbach 18)

-which is another way to say that these endings cannot be decided at random. The modernists, who broke the line with more violence than had ever been done before and, in so doing, defined the paradigm in which an important part of American poetry was written for a century, were deeply aware of the necessity, while turning, to avoid turning loose. "No verse is free for the man who wants to do a good job," said Eliot (a reasonably good poet) (37); and no break, in these matters, can be taken too soon either.

The importance of Eliot's and Pound's theories and practices regarding the theme of this issue (and regardless of the bias and limitations of its editor's expertise) makes Benoît Tadié's commentary on his recent French translation of The Waste Land a particularly relevant introduction to the articles presented here. Tadié, who was kind enough to answer a few questions on his work, insists on presenting it as scholarly rather than poetic. His translation is nonetheless in close conversation with the poem, in a way that is both learned and creative. In particular Tadié discusses Eliot's breakthroughs in relation to the frame of current prosody, that "first heave" which Pound fostered and took even further, and the second heave that lurks immediately behind and that is made necessary by the essential disquietude towards the act of breaking.

of the papers collected here only one is concerned with a writer who predates the breakthrough of Modernism, Emily Dickinson. Instead of rehashed dashes, Antoine Cazé chooses another subject matter, the "envelope poems," and thus offers a rare insight into the most material aspect of writing. Cazé introduces the meta-poetic dimension of the break, which is about "the end of the line" (Longenbach 12-25) in all senses of the phrase-that end of the line on which many later meta-commentaries are to be found. The "envelope poems" are also texts addressing the definition of poetry, in this case (in Cazé's words) "the limits between the poetic and the epistolary." The 
seemingly contingent break of the cellulose fibers itself leads to the question of versification as cut prose, a problem we then see arising, interestingly, with a poet who was not herself a vocal proponent of free verse.

15 Marianne Moore too was averse to the total absence of meter; her syllabic lines, though at odds with English accentual prosody, obey precise (if not necessarily meaningful) numeric patterns that create breaks within sentences and sometimes within words. Aurore Clavier shows that her particular rhythms also have to do with cutting prose, with "a reluctance to choose between the sentence and the line, between the apparent continuity of oral speech and written prose on the one hand and the trimming of verse on the other." This reluctance leads not only to that tension between the measure of the line and that of the syntax but to Moore's recurrent rewritings of her poems, which mostly involved cutting them anew.

Clavier describes Moore's poems as "sight stanzas," a phrase she takes up from critic Eleanor Berry who was herself quoting Philip K. Jason. Jason meant by that the "sham poetry" exposed or feared by many; but Berry on the contrary revalued it as something beyond an optical illusion: lines which, by being broken, defamiliarize an otherwise prosaic text. This specifically visual aspect of line breaks is further discussed in two papers concerned with poets who were also visual artists, Josef Albers and Susan Howe. Vincent Broqua, who closely studied the Albers archive at the Josef and Anni Albers Foundation, chooses here to focus not only on the artist's obvious (and so far littlestudied) poetic work, but also on pieces of writing found in his notebooks and on pedagogical texts. In the particular context of the experience of exile and of writing in a foreign language, Broqua shows, Albers' enjambments testify to an acute attention to the materiality of the page and to the theatricality of poetry, as well as to the ambiguity of the line itself, as both a poetic unit and a key graphic element.

In Susan Howe's Debths, Andrew Eastman explains, "sections of block-like poems alternate with series of her 'type-collages,' strips or fragments of prose or verse text pasted over each other and then photocopied; in these works, letters, words, and lines have been scissored through while syntax is necessarily discontinuous, leaving partially-legible scraps of printed matter: text in tatters." While the page naturally appears as Howe's basic unit of composition, Eastman chooses to consider what her collages do to the line itself, how they break it externally and also internally, through inner caesurae, and act as a provocative interrogation of reading practices, while continuing the conversation about the way the spatial organization of a text conditions and plays with generic expectations.

As Eastman shows, however, the way Howe deals with lines is not strictly visual, and "these poems work at the juncture of visual and aural": the way the text is organized on the page also invites one to ask how it should be read, what its rhythms and silences should sound like. Anna Aublet's essay offers a further insight into the dynamic relationship between the written text and its oral rendition. She finds in Ginsberg's books (especially Howl) and recordings a dismissal of the visual or material text as secondary and a focus on the corporality of poetic performance, in which, in Ginsberg's words, "[t]he main line of poetry is the breath, not the page." As such, Ginsberg uses the the long, breathless line not only as a reference to Whitman but also as a way to manifest his rejection of the broken, "free verse" (yet rhythmically constrained) lines of the Modernists, especially Williams. Aublet points out the ethical dimension of the long line, which can take its full scope and breadth only as an uninterrupted, unbroken 
unit. Ginsberg's performances blur the boundaries between writing, speaking and singing; in this case, what matters is not so much the tensions between these poles as the aesthetic and political values attributed to them.

Mathieu Duplay is also concerned with performative art as he studies what may also be regarded as a sung poem, John Adams's opera Nixon in China; but he proposes to consider Alice Goodman's published libretto also as "a stand-alone text of poetry," independent of its musical setting. Goodman, Duplay reminds us, is herself a scholar well-versed in Renaissance and seventeenth-century poetry. Although she is the youngest poet among those studied in the articles collected here, her work is probably the one in which the question of meter, in the traditional sense of the word, is the most pressing. She does not write in free verse, but mostly in iambic tetrameters; yet Duplay shows that she does not so much emulate seventeenth-century prosody as parody it, through a number of enjambments that do not fit in the metric frame, such as words cut in two or pronouns artificially placed at the end of a line. The paper then closely analyses when and how Adams chose to exploit Goodman's line breaks. "Whenever Adams feels that a line break serves no clear semantic purpose," Duplay writes, "he sets the text as if it were prose, privileging syntactical continuity at the expense of meter." In this case the aural transposition of the versified text becomes the moment of a possible denial of its versified status, or rather, the subtle discussion of versification as a ghostly, more or less relevant presence.

While Aublet stresses the political quality of Ginsberg's long line, Duplay insists that, despite its title, Adams' opera is concerned primarily with aesthetic, not political or diplomatic, questions. However, in one of the most striking excerpts of Goodman's libretto he comments on (Madame Mao singing "the people hang / Upon my words"), the enjambment creates a cliffhanger whose effect is full of political innuendoes. The run-on line here also unveils something of the ontological dimension of the line break. Hölderlin famously commented on the caesura in Ancient Greece as opening an ontological impossibility, towards the unintelligible and death. Marie Olivier's contribution provides a striking example of a poet who, through lineation, explores loss and ontological hiatus, thus resonating with Hölderlin's statement. Olivier offers a reading of Louise Glück's latest collection, Faithful and Virtuous Night, in which free verse and prose alternate. She suggests seeing in Glück's lines a convergence of chasm and chiasmus through which a tensed temporality is at play-that of mourning, the consistent and continued theme of the book, but also that of an open gap between language and the world.

21 "When I picked up, the line was dead." Glück's line, quoted by Olivier in one of her paper's many close readings, could also sound like a metaphorical statement by a melancholy postmodern poet. Taken out of its context, it surprisingly echoes Ron Padgett's more obvious puns, which often act as meta-poetic comments as well as a series of memento mori ("you're next in line"). Although it is more than easy to read Padgett as a light and funny poet, Olivier Brossard, without denying him these qualities, takes him seriously and, in fact, shows that his line breaks are quite systematically at the core of his meta-textual poetics. In that respect, Padgett's lines condense and make explicit much that has been said in previous papers, as if they were located at the (temporary) end of a line, from Dickinson's work with the materiality of broken paper to Susan Howe's mournfully playful title Secret history of the dividing line. 

(in French) and Johanna Drucker (in English), belong to that same lineage as they take the line itself both as subject and matter, medium and message. These texts are selfsufficient and it would spoil them to comment on them here; let us simply note that, through the reflexive use they make of the poetic line, they manifest the essential disquietude which, retrospectively, provides all the texts collected here, academic or creative, with a common theme and a common method. It was a pleasure and honor to edit this special issue and I am grateful to all the contributors for their patience, their kindness and their general brilliance.

A few last lines of acknowledgements: the symposium that is at the origin of this journal issue, and to which some of the contributors participated, was organized by Sophie Mayer and myself with the support of the Sorbonne-Nouvelle and Paris 8. It was lit up and enlightened by Mayer's stunning readings of poems, which provided much more than an illustration of the phonetic, oral, and performative aspects of the line breaks at stake in each paper. They let both participants and audience experience the effects and affects of the texts under discussion and go beyond the sheer intellectuality of academic conferences to turn the symposium into a rare and joyous moment. It was prolonged by Olivier Cadiot's talk during which, as a translator and writer, he provided a final twist to our reflections. Finally, let me thank here Cécile Roudeau who, as head editor of Transatlantica, has done much more than providing me with guidelines for the publication of this issue. In an article for Quaderna, Cécile took the line as an instrument of categorization and of separation, the first dimension of a grid soon to be imposed on maps, lands, people (Roudeau); she welcomed these line breaks imposing no other grid than that of scholarly rigor and friendly flexibility-I am all the more grateful for her patience and kindliness.

\section{BIBLIOGRAPHY}

BEAUVAIS Clémentine. Les ados adorent les romans en vers. 8 December 2017, www.hachette.fr/ interview/clementine-beauvais-les-ados-adorent-les-romans-en-vers.

ELIOT, Thomas Stearns. On Poetry and Poets. London: Faber and Faber, 1957.

FRANK, Robert, and Henry M. SAYRE, eds. The Line in Postmodern Poetry. Champaign: University of Illinois Press, 1988.

HULME, T.E. “A Lecture on Modern Poetry.” T.E. Hulme, by Michael Roberts. Manchester: Carcanet New Press, 1982, pp. 258-270.

LERNER, Ben. Leaving the Atocha Station. EBook, Minneapolis: Coffee House Press, 2011.

LERNER, Ben. The Hatred of Poetry. EBook, New York: FSG Originals, 2016.

LEVERTOV, Denise. “On the Function of the Line.” Chicago Review, vol. 30, no. 3, 1979, p. 30-36.

LONGENBACH, James. The Resistance to Poetry. Chicago: University of Chicago Press, 2004.

Transatlantica, 1 | 2021 
PERELMAN, Bob. The Marginalization of Poetry: Language Writing and Literary History. Princeton: Princeton University Press, 1996.

PERLOFF, Marjorie. "Lucent and Inescapable Rhythms: Metrical 'Choice' and Historical Formation.” The Line in Postmodern Poetry. Eds. Robert Frank and Henry M. Sayre. Champaign: University of Illinois Press, 1988, p. 13-40.

PERLOFF, Marjorie. “The Linear Fallacy.” The Georgia Review, vol. 35, no. 4, 1981, p. 855-869.

PINSKY, Robert. The Situation of Poetry. Princeton: Princeton University Press, 1978.

POUND, Ezra. Collected Early Poems of Ezra Pound. Ed. Michael John King. New York: New directions, 1976.

POUND, Ezra. Pavanes and Divisions. New York: A.A. Knopf, 1918.

POUND, Ezra. The Cantos. New York: New Directions, 1989.

ROUDEAU, Cécile. “Fuite de la ligne. De la catégorie en Amérique." Quaderna, no. 1, December 2012, quaderna.org/fuite-de-la-ligne-de-la-categorie-en-amerique/.

SCULLY, James. "Line Break.” The Line in Postmodern Poetry. Eds. Robert Frank and Henry M. Sayre. Champaign: University of Illinois Press, 1988, p. 97-131.

WILLIAMS, William Carlos. The Collected Poems of William Carlos Williams, Vol. 1: 1909-1939. New York: New Directions, 1986.

\section{AUTHOR \\ CHLOÉ THOMAS}

Université d'Angers 